\title{
Glyphosate vulnerability explains changes in root-symbionts propagules viability in pampean grasslands
}

\author{
M. Druille ${ }^{\text {a,* }}$, M.N. Cabello ${ }^{\text {b,c }}$, P.A. García Parisi ${ }^{\text {a }}$, R.A. Golluscio ${ }^{\text {a }}$, M. Omacini a \\ a IFEVA, Faculty of Agronomy, University of Buenos Aires, CONICET, Av. San Martín 4453, Buenos Aires C1417DSE, Argentina \\ b Instituto Spegazzini, Faculty of Natural Sciences and Museum, National University of La Plata, Av. 53 No 477, La Plata B1900AVJ, Argentina \\ ${ }^{\mathrm{C}}$ CICPBA, Argentina
}

\section{A R T I C L E I N F O}

\section{Article history:}

Received 9 July 2014

Received in revised form 10 December 2014

Accepted 15 December 2014

Available online 8 January 2015

\section{Keywords:}

AMF spores

Rhizobium propagules

Non-target organisms

Glyphosate

Pampean grasslands

\begin{abstract}
A B S T R A C T
Research into the impact of agricultural practices on plant symbionts is essential for understanding the factors that modulate plant community productivity and diversity. Although glyphosate is used worldwide as an herbicide, its effects on root symbionts under natural conditions have not been sufficiently studied. We performed a field experiment to evaluate the influence of glyphosate, used for promoting winter forage production, on the viability of arbuscular mycorrhizal fungi (AMF) and rhizobium propagules and other ecosystem traits in native grasslands. The number of viable propagules was strongly reduced with a single application at the recommended dose. Spore viability reduction was dependent on AMF species. Furthermore, changes in plant community composition and soil salinity were detected, which may eventually influence these symbionts in the future. Considering the low nutrient availability and high root-symbiont dependency of several species with forage value, repeated applications might lead to a loss in the grassland diversity and productivity, decreasing livestock production. Application of sublethal doses of this herbicide could avoid these damages, although success in increasing winter forage production would be less. Our results are relevant for understanding the effects of glyphosate on non-target species and designing sustainable land management systems.
\end{abstract}

(c) 2014 Elsevier B.V. All rights reserved.

\section{Introduction}

There is great interest in understanding the factors that determine the persistence of plant symbionts because they are closely related to ecosystems productivity and stability (van der Heijden et al., 2006, 2008; Klironomos et al., 2011). In the past, ecologists have tried to explain the organization of plant communities focusing on the negative biotic interactions among plants (Tilman, 1994) and their enemies, such as herbivores (Olff and Ritchie, 1998; Bakker et al., 2006) and pathogens (van der Putten and Peters, 1997; Mills and Bever, 1998; van der Putten and van der Stoel, 1998; Maron et al., 2011), and on the impact of climate and soil abiotic properties (Milchunas et al., 1989; Robinson et al., 1998; Knapp et al., 2002). However, it is increasingly recognized that positive interactions between plants and microbial symbionts play a central role in determining plant community composition, diversity and productivity (van der Heijden et al., 1998a; Clay and Holah, 1999; van der Heijden

\footnotetext{
* Corresponding author. Tel.: +549 114524 8000x4056.

E-mail address: druille@ifeva.edu.ar (M. Druille).
}

et al., 2006; Klironomos et al., 2011). Mechanisms involved may be diverse, including resource acquisition, protection against antagonists and habitat modification (Kothamasi et al., 2010; Omacini, 2014).

Among plant microbial symbionts, the most important are arbuscular mycorrhizal fungi (AMF) and nitrogen fixing bacteria, considering their benefits to host plants, and their worldwide distribution in different types of ecosystems (Kahindi et al., 1997; Zahran, 1999; Brundrett, 2009). Both types of soil-borne microbes form beneficial associations with their hosts. AMF colonize more than $80 \%$ of terrestrial plant species (Smith and Read, 2008) enhancing their growth and uptake of immobile mineral nutrients, particularly phosphorous (Smith et al., 2003), and improving water relations (Smith and Read, 2008). Rhizobia is a group of soil bacteria (Rhizobium,Bradyrhizobium, Mesorhizobium, Sinorhizobium, or Azorhizobium spp.) that reduce atmospheric $\mathrm{N}_{2}$ into $\mathrm{NH}^{4+}$ after becoming established in root nodules of legumes (Sprent, 2007) thus enhancing their host growth and, ultimately, N availability for other plants (Høgh-Jensen and Schjoerring, 2000). AMF and rhizobia spread among hosts through the soil; therefore, variations in the number of viable propagules have an impact on legumes and plants with high mycorrhizal dependency, altering 
plant composition and diversity (Denison, 2000; O'Connor et al., 2002).

Several studies have shown that human activities, such as tillage (Ferreira et al., 2000; Schalamuk and Cabello, 2010), fertilization (Beard and Hoover, 1971; Bradley et al., 2006) and use of pesticides (Johnson and Pfleger, 1992; Sugavanam et al., 1994; Singh and Wright, 2002) can alter the performance of AMF and rhizobia. Within pesticides, glyphosate ( $N$-phosphonomethyl glycine) is one of the most studied because it is a broad-spectrum herbicide massively used worldwide for its effective weed control and low toxicity in mammals (Busse et al., 2001). Being rapidly degraded by microorganisms or adsorbed on soil particles, impacts of this herbicide on non-target microorganisms were assumed to be insignificant under field conditions (Anderson et al., 1993). Nevertheless, contradictory effects have been reported in agricultural crops, being positive, negative or neutral on AMF root colonization (Morandi, 1989; Mujica et al., 1999; Malty et al., 2006; Ronco et al., 2008; Powell et al., 2009; Savin et al., 2009) and neutral or negative on AMF spores (Giovannetti et al., 2006; Malty et al., 2006; Pasaribu et al., 2011). In relation to rhizobia, negative effects of glyphosate application on soybean nodulation and $\mathrm{N}_{2}$ fixation have been reported (King et al., 2001; Reddy and Zablotowicz, 2003; Zablotowicz and Reddy, 2004).

The use of glyphosate is not limited to agricultural systems; it is also used in forest plantations, recreational areas and natural grasslands with the aim of eradicating exotic species or promoting winter forage species (Cole and Lunt, 2005; Barnes, 2007; Rodriguez and Jacobo, 2010; Helander et al., 2012). Glyphosate application and nitrogen fertilization are frequently used in native grasslands of the Flooding Pampa (Argentina), with the aim of increasing winter productivity (Rodriguez and Jacobo, 2010). This herbicide is sprayed in late summer to reduce competition of forbs and $\mathrm{C}_{4}$ grasses, improving germination and establishment of cool-season annual $C_{3}$ grasses (Rodriguez and Jacobo, 2010). This practice increases winter forage production per hectare and allows improvement of stocking rate and meat production (Bilello and Zeberio, 2002). Greenhouse experiments have demonstrated that glyphosate application reduces AMF spore viability in soil from these grasslands and subsequently mycorrhizal colonization of plants (Druille et al., 2013a,b,b). A large reduction in spore viability was detected even when a dose that damaged but did not kill Lolium multiflorum plants (sub-lethal dose) was used, which demonstrates that ecosystem components may have different vulnerability to glyphosate. Additionally, it has been shown that total basal vegetation cover and plant species richness (mainly cool-season perennial grasses, warm-season tussock grasses, warm-season legumes) are negatively affected in grazed grasslands after several years of applying glyphosate and grazing (Rodriguez and Jacobo, 2010).

The objective of this study was to evaluate the effect of glyphosate application on soil availability of plant-symbiont propagules. The study was conducted in a Flooding Pampa grassland of Argentina, in which the abundance and viability of AMF and rhizobium propagules were evaluated after different doses of glyphosate application in late of summer. Although there are three types of AMF propagules (spores, external mycelium and infected root segments) we focused on spores, considering its importance as a source of propagules for AMF perpetuation and spread in the system and for optimal root colonization of plants (Smith and Read, 2008).

Additionally, changes in the plant community composition, basal cover of vegetation and litter, and soil salinity (measured as electrical conductivity of saturation extract) were analyzed, taking into account the close relationship between these variables and plant symbiont propagules (Singleton et al., 1982; Abbott and Robson, 1991; Craig et al., 1991). In these grasslands, a decrease in vegetation cover may generate an increase in electrical conductivity, due to the ascent of salts from the B horizon toward the surface in periods of high temperature (Taboada et al., 2011). Our hypothesis is that under field conditions, glyphosate application, even at sublethal doses, reduces viable propagules of AMF and rhizobia, and increases soil salinity by reducing vegetation cover.

\section{Materials and methods}

\subsection{Study site}

The experiment was conducted in a humid mesophytic meadow, located near Ignacio Correas, in the northeast of the Flooding Pampa ( $35^{\circ} 01^{\prime} \mathrm{S}, 57^{\circ} 50^{\prime} \mathrm{W}$ ) (Perelman et al., 2001). The average annual temperature in the region is $15.9^{\circ} \mathrm{C}$ and annual precipitation is $885 \mathrm{~mm}$ year $^{-1}$ (Perelman et al., 2001). The soil is classified as a Typic Natraquoll/US Soil Taxonomy (Mollic Gleyic Solonetz/FAO Soil Taxonomy), characterized by an acidic, non-saline A1 horizon and a saline, highly alkaline B2 horizon (Lavado and Taboada, 1988), with 3.5\% organic matter and 7 ppm P. Even though this type of grassland is commonly treated with glyphosate in late summer (Rodriguez and Jacobo, 2010), the study site had no history of herbicide treatment. The dominant species of the grassland are Stenotaphrum secundatum (Walt.) Kuntze, Phyla canescens (Kunth) Greene, Lotus tenuis Waldst. \& Kit, Eryngium ebracteatum Lam., L. multiflorum Lam., Paspalum dilatatum Poir., Bothriochloa laguroides (DC) Herter, Setaria geniculata (Lam.) Beauv., Chaetotropis elongata (Kunt) Björkman, Panicum gouinii Fournier and Paspalum vaginatum Sw. Before glyphosate application, vegetation cover was measured in each experimental unit according the line intercept method (Canfield, 1941). The grassland presented a percentage of vegetation cover, litter and bare soil of $69 \%, 14 \%$ and $17 \%$, respectively.

\subsection{Experimental design and herbicide application}

Experimental units were 30 plots of $2.25 \mathrm{~m}^{2}$ randomly selected, with a similar floristic composition. The experiment had a completely randomized design with three glyphosate levels: 0,384 and $1440 \mathrm{~g}$ acid equivalent ha ${ }^{-1}$ (control, sublethal and recommended dose, respectively), with 10 replicates per treatment. Glacoxan ${ }^{\circledR}$ (48 g isopropylamine salt of glyphosate in $100 \mathrm{~cm}^{3}$ of inerts and adjuvants) was applied in late summer (15th March), using a knapsack sprayer with a $20 \mathrm{~L}$ tank, operating at constant 3 bar pressure. In control plots, the sprayer was used to apply water in the same volume as in plots treated with glyphosate. During the course of the experiment, plots were kept surrounded with electric wire to prevent cattle grazing.

\subsection{Measurements}

\subsubsection{Spore separation and identification}

Considering that AMF community is determined by host plant species (Bever, 2002), $300 \mathrm{~g}$ soil samples associated to roots of two species from different functional groups according to their lifeform and ability to form symbiotic relationships with $\mathrm{N}_{2}$-fixing organisms (i.e. the perennial legume $L$. tenuis and the perennial grass Paspalum dilatatum) were collected 15 days after glyphosate application. Soil cores ( $8 \mathrm{~cm}$ diameter) were taken to a depth of $10 \mathrm{~cm}$. Part of this rhizosphere soil was oven-dried $\left(105^{\circ} \mathrm{C}\right)$ to reach constant weight, in order to estimate soil moisture. With the remaining rhizosphere soil, two sievings were performed for spore extraction through wet sieving technique and decanting (Gerdemann and Nicolson, 1963), followed by sucrose gradient centrifugation (Walker et al., 1982). One of the extractions was used for spore number estimation, and the other one for measuring spore 
viability. To assess AMF identity, each morphotype was mounted on polyvinyl alcohol-glycerol-lactic acid (PVLG) and PVLG + Melzer reagent for identification. The spores were matched with species described by International Culture Collection of VA Mycorrhizal Fungi (INVAM, http://www.invam.caf.wvu.edu) and Błaszkowski (2012).

\subsubsection{Number and viability of AMF spores}

To estimate spore number, only externally healthy morphotypes were counted, by direct observation under stereomicroscope. Total spore number in each sample was corrected considering its moisture content to express this value per gram of dry soil. The An and Hendrix (1988) method was used to determine viable spores, developing a red color with the tetrazolium bromide vital stain MTT [3-(4,5-dimethylthiazol-yl)2,5-diphenyl-2H-tetrazolium bromide]. Spore suspensions were

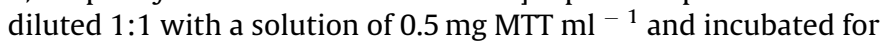
$40 \mathrm{~h}$. This determination was made primarily in the entire community and subsequently in the four species that dominate AMF spore community.

\subsubsection{Viable propagules of rhizobia}

Field soils were sampled in late spring (15th December) to determine the most probable number (MPN) of soil rhizobia capable of nodulating the selected host legume L. tenuis. Thirty $10 \mathrm{~cm}$-diameter soil cores at a depth of $10 \mathrm{~cm}$ were taken, one from each experimental unit. Each soil core was mixed, subsampled for determination of moisture content, and stored at $4{ }^{\circ} \mathrm{C}$ overnight. Five serial ten-fold soil dilutions with 4 repetitions each were prepared as described by Somasegaran and Hoben (1985) with $10 \mathrm{~g}$ of soil on $90 \mathrm{ml}$ of physiological solution for the first dilution step. Test plants growing under sterile conditions were inoculated with a $0.2 \mathrm{ml}$ aliquot of the corresponding dilution. Plants were kept in sterile growing chambers supplied with an adequate volume of a sterile $\mathrm{N}$-free nutrient solution. Plants were scored for nodulation 21 days after inoculation, considering as "positive" a plant with at least one functional nodule (determined by a pink color), and "negative" a plant without nodules. The MPN of rhizobia was determined considering the number of positive and negative plants in the serial dilutions (Somasegaran and Hoben, 1985). Four control plants were inoculated with the physiological solution used to prepare the dilutions. The four plants resulted negative for nodulation score.

\subsubsection{Vegetation sampling and soil electrical conductivity}

In late spring (15th December) measurements of vegetation and electrical conductivity were taken. Vegetation cover was measured according to the line intercept method proposed by Canfield (1941). As in previous studies conducted in these grasslands (Rusch and Oesterheld, 1997; Perelman et al., 2001; Rodriguez and Jacobo, 2010; Longo et al., 2013), plant species were classified into functional groups defined by life-form, phenology and the possibility to form symbiotic relationships with $\mathrm{N}_{2}$-fixing organisms: cool-season annual grasses (CSAG), cool-season perennial grasses (CSPG), warm-season grasses (WSG), cool-season legumes (CSL), warm-season legumes (WSL), sedges (S) and forbs (excluding legumes). Relative cover (\%) of each functional group and bare soil plus litter $(B S+L)$ were calculated from total basal cover. In estimating plant cover, both vegetation cover and litter were included.

Electrical conductivity (EC) is an easily measured and practical index of the total concentration of ionized solutes of a saturated soil (Rhoades et al., 1999). Therefore, to estimate soil salinity, three measurements of the EC of soil saturation extracts were performed in each plot, using a portable conductivity meter (HI993310,
HANNA ${ }^{\circledR}$, Rhode Island, USA) (Rhoades, 1982). Soil moisture was close to field capacity at the moment of measurements.

\subsection{Statistical analysis}

One-way analysis of variance (ANOVA) was performed to determine principal effects of herbicide doses on the total number of spores, spore viability and total number of viable spores (a separate ANOVA for each plant species rhizosphere). Plant cover and EC data were also analyzed using one-way ANOVA. Treatment means were compared using Tukey test when significant $F$ values were found. The significance level was set at $\alpha=0.05$. To obtain homogenous variances, percent data were arcsine square-root transformed before carrying out each analysis. Rhizobium number per gram of soil presented Poisson distribution and was analyzed using a generalized linear model (glm). Due to over dispersion of the data, "quasipoisson" family was specified to the model. The significance of the parameters estimated by the model was tested by applying Likelihood Ratio Test (LRT, R-cran Software). Floristic composition was a synthetic variable obtained by applying a Non-metric multidimensional scaling (NMS) ordination (Clarke, 1993 ) to plant species abundance (\% cover) data. We performed one NMS per replicate of each treatment. With the location of each point on both axes a multivariate analyses of variance (MANOVA) was performed (Hotelling Test with Bonferroni correction). Statistically significant MANOVAs were followed up by simple ANOVAs and Tukey's post hoc tests to explore the trends observed for each individual parameter.

\section{Results}

\subsection{Viable propagules of AMF and rhizobia}

Total number of AMF spores present in the communities associated to $L$. tenuis and to $P$. dilatatum rhizosphere varied between 419 and 561 spores/100 g dry soil, respectively, and did not differ between the treatments $\left(F_{2,27}=1.69, P=0.202\right.$ and $F_{2,27}=0.22, P=0.807$, respectively). A total of 19 AMF morphospecies were identified in soil from all treatments (Supporting Information, Table 1). Four species accounted for $74 \%-89 \%$ from the total AMF spore community in all treatments: Funneliformis mosseae (T.H. Nicolson \& Gerd.) C. Walker \& A. Schüßler, Claroideoglomus etunicatum (W.N. Becker \& Gerd.) C. Walker \& A. Schüßler, Septoglomus constrictum (Trappe) Sieverd., G. A. Silva \& Oehl and Funneliformis caledonium (T.H. Nicolson \& Gerd.) C. Walker \& Schüßler.

Spore viability was affected by glyphosate application in the AMF community associated to $L$. tenuis $\left(F_{2,27}=4.21 ; P=0.025\right)$ and $P$. dilatatum $\left(F_{2,27}=11.69, P<0.001\right)$. There was a significant reduction in viability of $31 \%$ and $35 \%$ in the AMF community associated to $L$. tenuis and $P$. dilatatum, respectively, when the highest dose of the herbicide ( $1440 \mathrm{~g}$ ae ha ${ }^{-1}$ ) was applied. In the case of the AMF community associated with $L$. tenuis, a tendency to decrease was demonstrated when applying 384 ae ha $^{-1}$ (see Tukey's results in Fig. 1a). Therefore, the number of viable spores (resulting from multiplying the number of spores of each treatment by the percentage of viability) was reduced by $36 \%$ and $41 \%$ when the higher dose of glyphosate was applied (Fig. $1 \mathrm{~b}$ ) in both communities $\left(F_{2,27}=3.44, P=0.046\right.$ and $F_{2,27}=5.80$, $P=0.008$ in $L$. tenuis and $P$. dilatatum, respectively).

When focusing the analysis on the four species dominating the community (Supporting Information, Table 1), a significant interaction between species and glyphosate was observed $\left(F_{6,115}=2.25, \mathrm{P}=0.043\right)$. Spore viability was significantly reduced by $52 \%$ and $72 \%$ in F. caledonium and S. constrictum, respectively, but not in the other two species: F. mosseae, C. etunicatum (Fig. 2). 

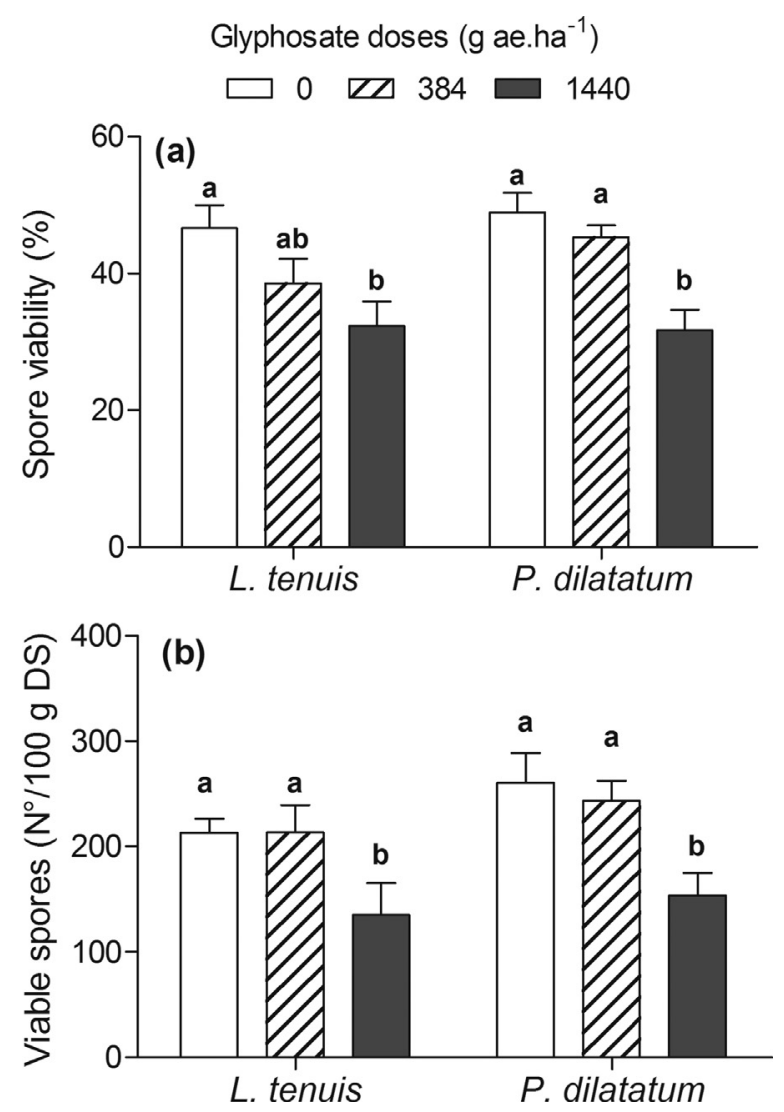

Fig. 1. Percent of spore viability (a) and number of viable spores (b) associated to $L$. tenuis and $P$. dilatatum soils, subjected to different glyphosate doses. Values represent means \pm S.E. of ten repetitions. The same letter above bars indicates that the values did not differ significantly between treatments according to ANOVA and Tukey test $(P \leq 0.05)$

Glyphosate application significantly reduced the viable propagules of rhizobia $\left(\chi_{2}^{2}=10.9, P=0.004\right)$. In soils treated with the recommended dose, viable propagules of rhizobia was more than ten-fold lower than in untreated soils (Fig. 3).

\subsection{Floristic composition}

A total of 38 plant species were identified in plots from all treatments (Supporting Information, Table 2). Plant functional

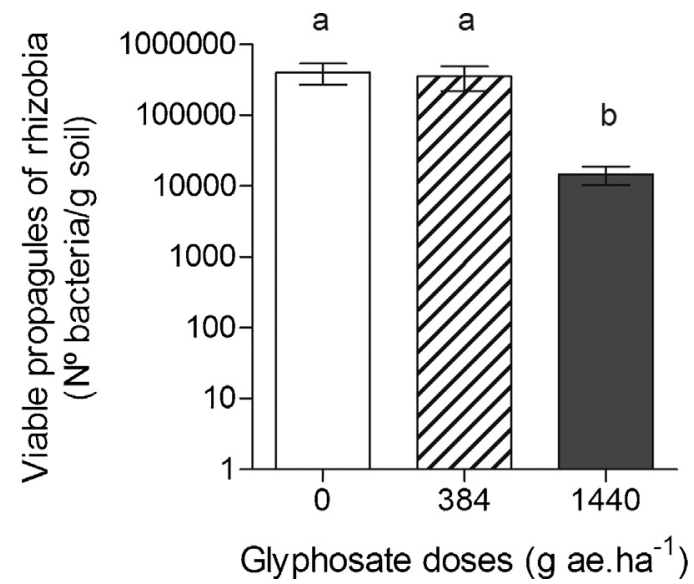

Fig. 3. Rhizobial bacteria density in soils treated with different doses of glyphosate according to most probable number estimation after ten-fold successive dilutions of the soil solution. Values represent means \pm S.E. of ten repetitions. The same letter above bars indicates that the values did not differ significantly between treatments according to ANOVA and Tukey test $(P \leq 0.05)$.

group composition diverged among the three doses as demonstrated by the non-metric multidimensional scaling and MANOVA analyses $(P<0.001)$. The best solution for the NMS ordination was made up by two significant axes (Monte Carlo test, $P=0.039$ ) with a cumulative $r^{2}$ of 0.91 . The final stress for 2-dimensional solution was 14 . Axis 1 of the ordination diagram of the multivariate trait analysis (NMS) was closely and negatively correlated with cool-season annual grasses (CSAG, $r=0.73$ ), bare soil and litter $(\mathrm{BS}+\mathrm{L}, \quad r=0.91)$, and positively correlated with cool-season perennial grasses (CSPG, $r=0.89$ ), and axis 2 was closely and positively correlated with warm-season grasses (WSG, $r=0.73$ ) and warm-season legumes (WSL, $r=0.53$ ) (Fig. 4).

\subsection{Vegetation cover and electrical conductivity}

Vegetation cover was reduced by herbicide application $\left(F_{2,27}=9.69, P<0.001\right)$, obtaining a similar reduction when doses of 384 and 1440 ae ha $^{-1}$ were applied. In contrast, electrical conductivity was increased by herbicide application $\left(F_{2,27}=8.64\right.$, $P=0.003$ ) being significantly higher in plots treated with the highest dose of glyphosate, surpassing the electrical conductivity of the control plots by $50 \%$ (Fig. 5).

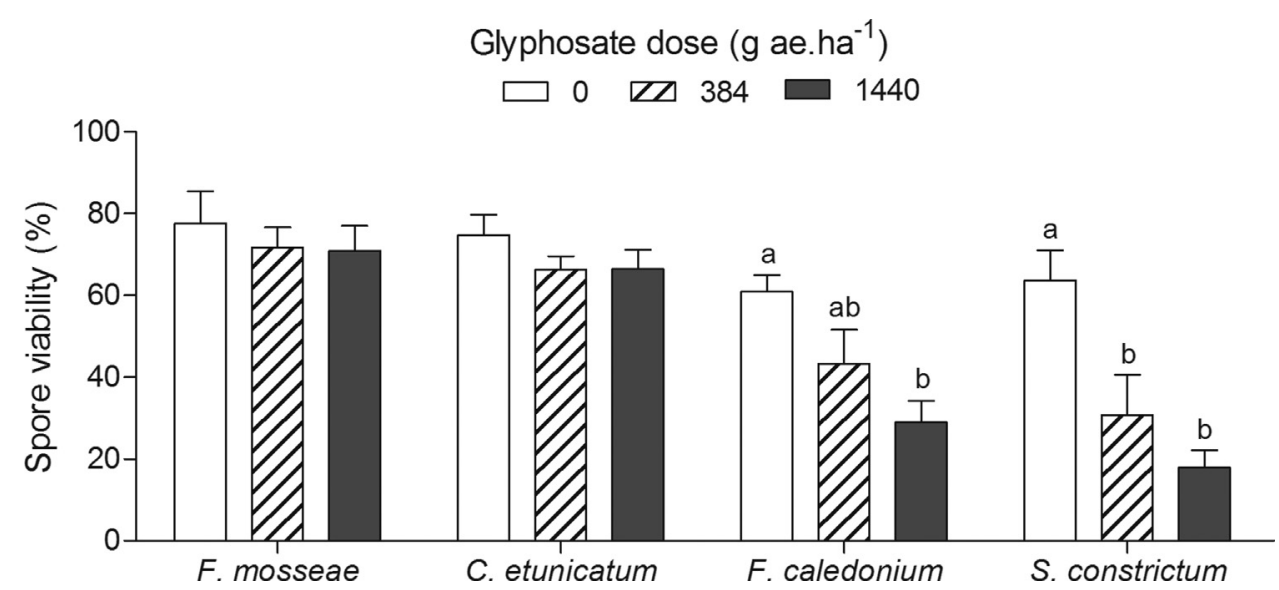

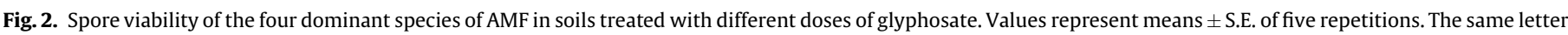
above bars indicates that the values did not differ significantly between treatments according to ANOVA and Tukey test $(P \leq 0.05)$. 


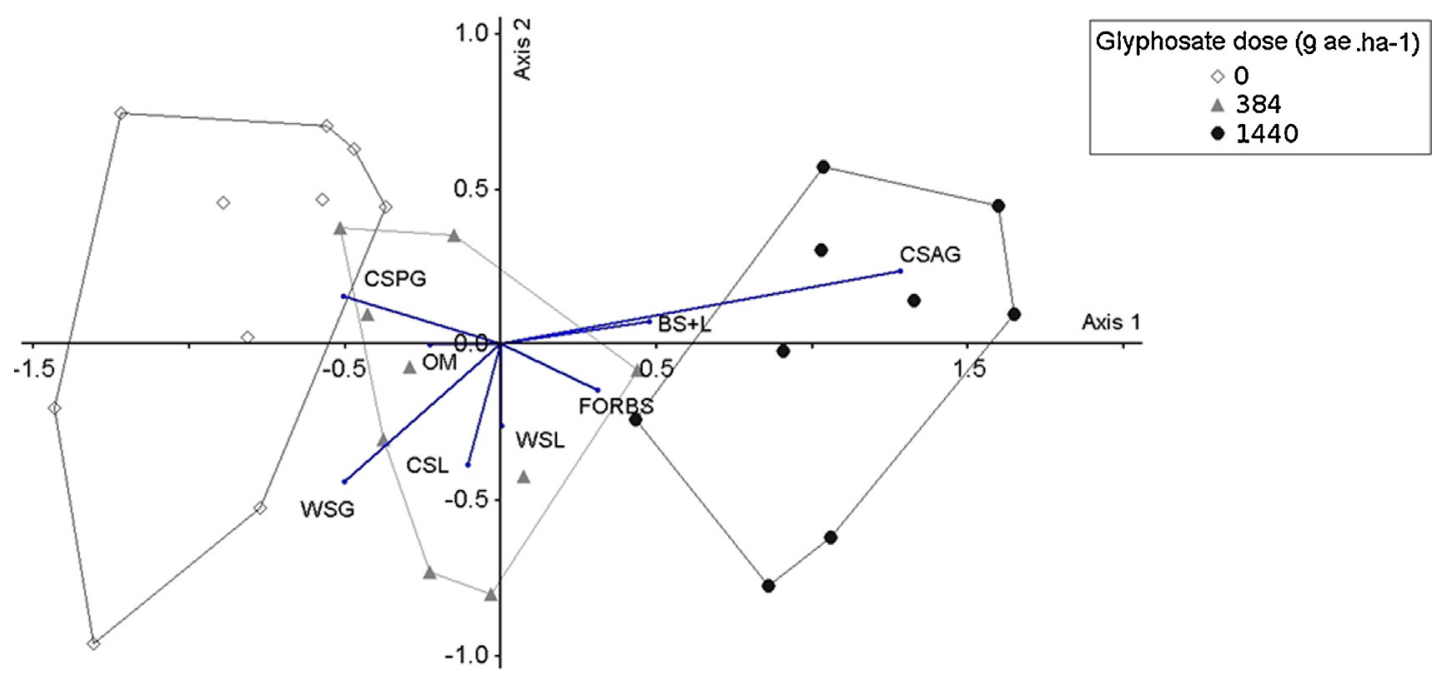

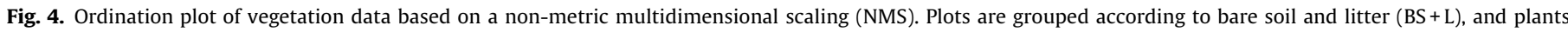

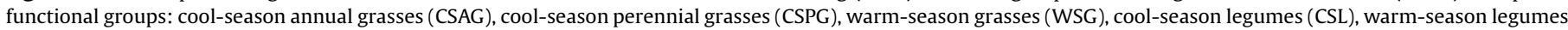
(WSL), sedges (S) and forbs. Length and direction of the vectors shown represent the correlations between functional groups and each axis.

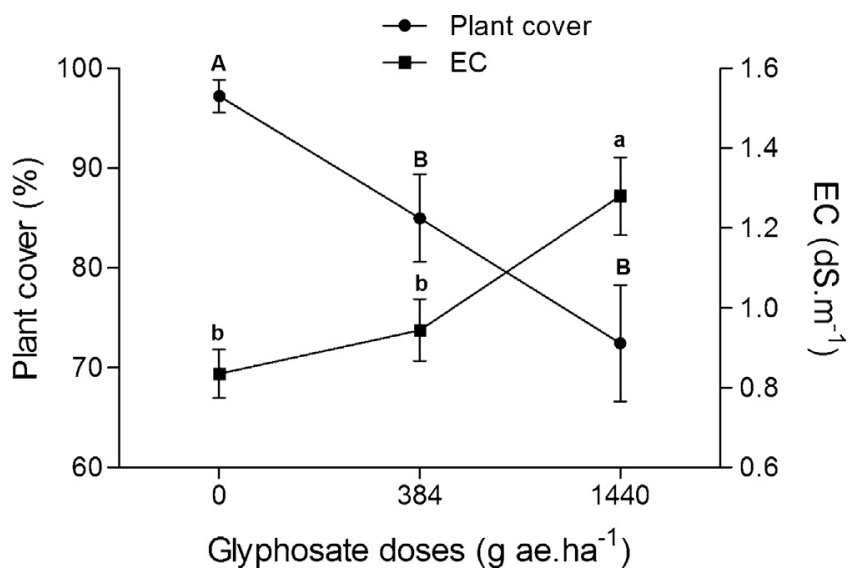

Fig. 5. Plant cover (\%) and electrical conductivity in plots treated with different glyphosate doses $\left(0,384\right.$ and 1440 ae ha $\left.^{-1}\right)$. Values represent means \pm S.E. of ten repetitions. Same letters indicate that values are not significantly different between treatments according to ANOVA and Tukey test $(\alpha<0.05)$.

\section{Discussion}

To our knowledge, this is the first time that the influence of glyphosate application on root-symbionts in native grasslands is studied under field conditions. Our results indicate that this herbicide negatively affects AMF and rhizobia propagule viability, when the recommended dose is applied. Given the benefits that these symbionts confer to their host plant, it is likely that nutrient availability and protection against pathogens would be reduced if propagules viability decreased, and external inputs such as pesticides and fertilizers would be required to maintain productivity and quality of these grasslands (Tikhonovich and Provorov, 2007; Gianinazzi et al., 2010; Andrews et al., 2011). This intensification of forage production systems may unfavorably impact on economic results and on the environment (Tilman et al., 2001).

AMF spore viability was reduced in the entire community and in two of the four dominant species. This result suggests that the lack of response found in the abundance of spores may be explained by the fact that after the application of drastic treatments, seemingly alive spores, which are actually dead, may persist in soil for extended periods (McGraw and Hendrix, 1986). Therefore, it could be argued that the AMF propagule availability was reduced due to one glyphosate application, since the percentage of viability decreased. Furthermore, AMF community structure may also be affected, as the reduction in viability was not similar between the four species that dominated spore community. A decrease in the relative abundance of $S$. constrictum and $F$. caledonuim and an increase in $C$. etunicatum and $F$. mosseae might be expected as direct effects of this herbicide. These results agree with those reported by Sheng et al. (2012), who detected changes in the structure of the AMF community with glyphosate application in agricultural crops, with $F$. mosseae being less sensitive to this herbicide. These changes in AMF relative abundance and identity may eventually alter plant community composition and diversity, for example through the modification of plant competition interactions (van der Heijden et al., 1998a,b,b; Scheublin et al., 2007).

Similarly as described above for AMF, the number of viable propagules of rhizobia was also decreased in plots treated with 1440 ae ha $^{-1}$ of glyphosate. Previous studies reported negative effects of this herbicide on nodulation (Reddy et al., 2001; dos Santos et al., 2005) and bacteroid nitrogenase activity (Hernandez et al., 1999) under controlled conditions, and nodule biomass in soybean under field conditions (Reddy and Zablotowicz, 2003). Moreover, it has been shown that glyphosate sensitivity depends on the strain of rhizobia (Zabaloy and Gómez, 2005), which could lead to changes in the community of these symbionts with repeated applications of this herbicide. The reduction in rhizobium propagule availability in natural grasslands could lead to a loss of basal legume cover, thus affecting soil $\mathrm{N}$ pools, productivity and forage quality (Graham and Vance, 2003).

Indirect effects of glyphosate application on root-symbiont propagules could be expected, mediated by the changes detected in plant community structure. On the one hand, the shift in the floristic composition in plots treated with glyphosate once, mainly explained by a reduction in $\mathrm{C}_{4}$ grasses and legumes and an increase in forbs basal cover, may eventually affect AMF community (Bever et al., 1996; Johnson et al., 2004). In this study, the detected decrease in AMF spore viability only reflects a direct effect of glyphosate, since it was estimated 15 days after application, when no changes in floristic composition were still evident. The reduction in legume cover may, in turn, compromise rhizobium community, since their fitness depends on the reproductive success during the symbiotic stage (Denison, 2000). On the other 
hand, plots treated with 1440 aeha $^{-1}$ presented higher soil salinity, probably due to the reduction in vegetation cover (Taboada et al., 2011). Previous studies have demonstrated that soil salinity delays germination and limits growth of hyphae from propagules of AMF (McMillen et al., 1998; Juniper and Abbott, 2006), and decreases the number of nodules per plant and the amount of nitrogen fixed per unit weight of nodules (Manchanda and Garg, 2008). Since rhizobium response was measured when the plant community structure was already modified due to glyphosate application (late spring), the observed reduction in their number of viable propagules could be due to direct and/or indirect effects of this herbicide.

More empirical research is required to evaluate the physiological or molecular mechanisms underlying root-symbionts response in our field study. Glyphosate causes the inhibition of the enzyme 5-enolpyruvylshikimate-3-phosphate (EPSP) synthase activity, leading to the inhibition of aromatic amino acid (phenylalanine, tyrosine, and tryptophan) biosynthesis, the reduction of protein production and the prevention of secondary product formation (Franz et al., 1997). Since the ESPS enzyme is present not only in plants but also in bacteria and fungi (Padgette et al., 1995), it can be speculated that alterations in the ESPS enzyme might explained, at least in part, the obtained results. Further studies should also evaluate possible toxic effects generated by adjuvants accompanying the active ingredient, or degradation products of the herbicide, as AMPA (aminomethylphosphonic acid).

A single glyphosate application at recommended dose was enough to reduce the number of viable propagules of AMF and rhizobia. The increase in the percentage of bare soil generated by glyphosate suggests that subsequent applications may magnify the detected damages since a larger amount of active product could contact the root-symbiont propagules. It has been demonstrated under greenhouse conditions that this herbicide reduces AMF spore viability when applied on bare soil, while spores remain intact when glyphosate is applied to plant foliage (Druille et al., 2013b). Considering the low nutrient availability and high rootsymbiont dependency of several species with high forage value (van der Heijden et al., 2008), repeated applications might lead to a loss in the grasslands quality and productivity, decreasing livestock production. The use of sublethal doses of glyphosate could avoid the damage generated on the root-symbionts, although success in the establishment of winter forage species would be less. Additionally, other tools that would achieve the same objective as glyphosate, such as intensive grazing or mechanical cutting (Deregibus et al., 1994; Arzadun and Mestelan, 2009), should be considered.

To conclude, we found that glyphosate can play a role in determining root-symbiotic relationships in grassland communities. In the short term, glyphosate application directly reduces the abundance of viable root-symbiont propagules. In the long term, this herbicide could indirectly affect AMF and rhizobium communities by modifying plant community and increasing soil salinity levels. Based on these results, we suggest that this management practice will affect the productivity and stability of these systems, where nutrient availability is low, decreasing livestock production. It is therefore necessary to continue studying the impact that this highly popular herbicide generates on non-target species in order to design sustainable land management systems.

\section{Acknowledgments}

This work was supported by grants to BID-PICT 01525, BID-PICT 00463, CONICET and CICPBA. The authors thank Fernando Cavagnaro and Miguel Taboada for his technical assistance, Beatriz Santos for correcting the English, Daniel Gonzalez Martino for allowing us to work on his farm. The authors also thank the comments of the editor and two anonymous reviewers that greatly improved the quality of the paper.

\section{Appendix A. Supplementary data}

Supplementary data associated with this article can be found, in the online version, at http://dx.doi.org/10.1016/j.agee.2014.12.017.

\section{References}

Abbott, L.K., Robson, A.D., 1991. Factors influencing the occurrence of vesiculararbuscular mycorrhizas. Agric. Ecosyst. Environ. 35, 121-150.

An, Z.Q., Hendrix, J.W., 1988. Determining viability of endogonaceous spores with a vital stain. Mycologia 80, 259-261.

Anderson, T.A., Guthrie, E.A., Walton, B.T., 1993. Bioremediation in the rhizosphere. Environ. Sci. Technol. 27, 2630-2636.

Andrews, M., Edwards, G.R., Ridgway, H.J., Cameron, K.C., Di, H.J., Raven, J.A., 2011. Positive plant microbial interactions in perennial ryegrass dairy pasture systems. Ann. Appl. Biol. 159, 79-92.

Arzadun, M.N.J., Mestelan, S.A., 2009. Late summer management can improve forage yield distribution and nutritive value in temperate grassland all rights reserved. No part of this periodical may be reproduced or transmitted in any form or by any means, electronic or mechanical, including photocopying, recording, or any information storage and retrieval system, without permission in writing from the publisher. Agron. J. 101, 584-591.

Bakker, E.S., Ritchie, M.E., Olff, H., Milchunas, D.G., Knops, J.M.H., 2006. Herbivore impact on grassland plant diversity depends on habitat productivity and herbivore size. Ecol. Lett. 9, 780-788.

Barnes, T.G., 2007. Using herbicides to rehabilitate native grasslands. Nat. Areas J. 27, 56-65.

Beard, B.H., Hoover, R.M., 1971. Effect of nitrogen on nodulation and yield of irrigated soybeans. Agron. J. 63, 815-816.

Bever, J., 2002. Host-specificity of AM fungal population growth rates can generate feedback on plant growth. Plant Soil 244, 281-290.

Bever, J.D., Morton, J.B., Antonovics, J., Schultz, P.A., 1996. Host-dependent sporulation and species diversity of arbuscular mycorrhizal fungi in a mown grassland. J. Ecol. 84, 71-82.

Bilello, G., Zeberio, G., 2002. Incorporación tecnológica en explotaciones ganaderas de tipo familiar de la Cuenca del Salado. Control de paja colorada (Paspalum quadrifarium) y rejuvenecimiento de rye-grass en pastizales naturales. Rev. Facultad Agronomía 22, 107-120.

Błaszkowski, J., 2012. Glomeromycota. In: Szafer, W. (Ed.), Institute of Botany. Polish Academy of Sciences, Kraków, Polonia.

Bradley, K., Drijber, R.A., Knops, J., 2006. Increased N availability in grassland soils modifies their microbial communities and decreases the abundance of arbuscular mycorrhizal fungi. Soil Biol. Biochem. 38, 1583-1595.

Brundrett, M.C., 2009. Mycorrhizas in natural ecosystems. Adv. Ecol. Res. 21, $171-313$.

Busse, M.D., Ratcliff, A.W., Shestak, C.J., Powers, R.F., 2001. Glyphosate toxicity and the effects of long-term vegetation control on soil microbial communities. Soil Biol. Biochem. 33, 1777-1789.

Canfield, R.H., 1941. Application of the line interception method in sampling range vegetation. J. For. 39, 388-394.

Clarke, K.R., 1993. Non-parametric multivariate analyses of changes in community structure. Aus. J. Ecol. 18, 117-143.

Clay, K., Holah, J., 1999. Fungal endophyte symbiosis and plant diversity in successional fields. Science 285, 1742-1744.

Cole, B.I., Lunt, I.D., 2005. Restoring kangaroo grass (Themeda triandra) to grassland and woodland understoreys: a review of establishment requirements and restoration exercises in south-east Australia. Ecol. Manage. Restor. 6, 28-33.

Craig, G.F., Atkins, C.A., Bell, D.T. 1991. Effect of salinity on growth of four strains of Rhizobium and their infectivity and effectiveness on two species of Acacia. Plant Soil 133, 253-262.

Denison, R.F., 2000. Legume sanctions and the evolution of symbiotic cooperation by rhizobia. Am. Nat. 156, 567-576.

Deregibus, V.A., Casal, J.J., Jacobo, E.J., Gibson, D., Kauffman, M., Rodriguez, A.M., 1994. Evidence that heavy grazing may promote the germination of Lolium multiflorum seeds via phytochrome-mediated perception of high red/far-red ratios. Funct. Ecol. 8, 536-542.

dos Santos, J.B., Ferreira, E.A., Kasuya, M.C.M., da Silva, A.A., Procópio, S.D.O., 2005. Tolerance of Bradyrhizobium strains to glyphosate formulations. Crop Prot. 24, 543-547.

Druille, Cabello, M.N., Omacini, M., Golluscio, R.A., 2013a. Glyphosate reduces spore viability and root colonization of arbuscular mycorrhizal fungi. Appl. Soil Ecol. 64, 99-103.

Druille, M., Omacini, M., Golluscio, R.A., Cabello, M.N., 2013b. Arbuscular mycorrhizal fungi are directly and indirectly affected by glyphosate application. Appl. Soil Ecol. 72, 143-149.

Ferreira, M.C., Andrade, de S., Chueire, de. D.O., Takemura, L.M., Hungria, S.M., 2000. Tillage method and crop rotation effects on the population sizes and diversity of bradyrhizobia nodulating soybean. Soil Biol. Biochem. 32, 627-637. 
Franz, J.E., Mao, M.K., Sikorski, J.A., 1997. Glyphosate: a unique global herbicide. American Chemical Society Monograph. American Chemical Society, Washington, DC.

Gerdemann, J.W., Nicolson, T.H., 1963. Spores of mycorrhizal Endogone species extracted from soil by wet sieving and decanting. Trans. Br. Mycol. Soc. 46, $235-244$.

Gianinazzi, S., Gollotte, A., Binet, M.-N., van Tuinen, D., Redecker, D., Wipf, D., 2010 Agroecology: the key role of arbuscular mycorrhizas in ecosystem services. Mycorrhiza 20, 519-530.

Giovannetti, M., Turrini, A., Strani, P., Sbrana, C., Avio, L., Pietrangeli, B., 2006. Mycorrhizal fungi in ecotoxicological studies: soil impact of fungicides, insecticides and herbicides. Prev. Today 2, 47-62.

Graham, P.H., Vance, C.P., 2003. Legumes: importance and constraints to greater use. Plant Physiol. 131, 872-877.

Helander, M., Saloniemi, I., Saikkonen, K., 2012. Glyphosate in northern ecosystems. Trends Plant Sci. 17, 569-574.

Hernandez, A., Garcia-Plazaola, J.I., Becerril, J.M., 1999. Glyphosate effects on phenolic metabolism of nodulated soybean (Glycine max L. Merr.). J. Agric. Food Chem. 47, 2920-2925.

Høgh-Jensen, H., Schjoerring, J.K., 2000. Below-ground nitrogen transfer between different grassland species: direct quantification by $15 \mathrm{~N}$ leaf feeding compared with indirect dilution of soil $15 \mathrm{~N}$. Plant Soil 227, 171-183.

Johnson, C.N., Pfleger, F.L., 1992. Vesicular-arbuscular mycorrhizae and cultural stresses. In: Bethlenfalvay, G.J., Linderman, R.G. (Eds.), Mycorrhizae in Sustainable Agriculture. ASA Special Publications, Madison, Wisconsin, pp. 71-99.

Johnson, D., Vandenkoornhuyse, P.J., Leake, J.R., Gilbert, L., Booth, R.E., Grime, J.P., Young, J.P.W., Read, D.J., 2004. Plant communities affect arbuscular mycorrhizal fungal diversity and community composition in grassland microcosms. New Phytol. 161, 503-515.

Juniper, S., Abbott, L.K., 2006. Soil salinity delays germination and limits growth of hyphae from propagules of arbuscular mycorrhizal fungi. Mycorrhiza 16, 371-379.

Kahindi, J.H.P., Woomer, P., George, T., de Souza Moreira, F.M., Karanja, N.K., Giller, K. E., 1997. Agricultural intensification, soil biodiversity and ecosystem function in the tropics: the role of nitrogen-fixing bacteria. Appl. Soil Ecol. 6, 55-76.

King, C.A., Purcell, L.C., Vories, E.D., 2001. Plant growth and nitrogenase activity of glyphosate-tolerant soybean in response to foliar glyphosate applications. Agron. J. 93, 179-186.

Klironomos, J., Zobel, M., Tibbett, M., Stock, W.D., Rillig, M.C., Parrent, J.L., Moora, M., Koch, A.M., Facelli, J.M., Facelli, E., Dickie, I.A., Bever, J.D., 2011. Forces that structure plant communities: quantifying the importance of the mycorrhizal symbiosis. New Phytol. 189, 366-370.

Knapp, A.K., Fay, P.A., Blair, J.M., Collins, S.L., Smith, M.D., Carlisle, J.D., Harper, C.W., Danner, B.T., Lett, M.S., McCarron, J.K., 2002. Rainfall variability, carbon cycling, and plant species diversity in a mesic grassland. Science 298, 2202-2205.

Kothamasi, D., Kiers, E.T., van der Heijden, M.G.A., 2010. Mutualisms and community organization. In: Verhouef, H.A., Morin, P.J. (Eds.), Community Ecology: Processes, Models and Applications. Oxford University Press, Oxford, pp. 179-192.

Lavado, R.S., Taboada, M.A., 1988. Water, salt and sodium dynamics in a Natraquoll in Argentina. CATENA 15, 577-594.

Longo, G., Seidler, T.G., Garibaldi, L.A., Tognetti, P.M., Chaneton, E.J., 2013. Functional group dominance and identity effects influence the magnitude of grassland invasion. J. Ecol. 101, 1114-1124.

Malty, J.D.S., Siqueira, J.O., Moreira, F.M.D.S., 2006. Efeitos do glifosato sobre microrganismos simbiotróficos de soja, em meio de cultura e casa de vegetação. Pesquisa Agropecuaria Brasileira 41, 285-291.

Manchanda, G., Garg, N., 2008. Salinity and its effects on the functional biology of legumes. Acta Physiol. Plant. 30, 595-618.

Maron, J.L., Marler, M., Klironomos, J.N., Cleveland, C.C., 2011. Soil fungal pathogens and the relationship between plant diversity and productivity. Ecol. Lett. 14, 36-41.

McGraw, A., Hendrix, J., 1986. Influence of soil fumigation and source of strawberry plants on population densities of spores and infective propagules of endogonaceous mycorrhizal fungi. Plant Soil 94, 425-434.

McMillen, B.G., Juniper, S., Abbott, L.K., 1998. Inhibition of hyphal growth of a vesicular-arbuscular mycorrhizal fungus in soil containing sodium chloride limits the spread of infection from spores. Soil Biol. Biochem. 30, 1639-1646.

Milchunas, D., Lauenroth, W., Chapman, P., Kazempour, M., 1989. Effects of grazing, topography, and precipitation on the structure of a semiarid grassland. Vegetatio 80, 11-23.

Mills, K.E., Bever, J.D., 1998. Maintenance of diversity within plant communities: soil pathogens as agents of negative feedback. Ecology 79, 1595-1601.

Morandi, D., 1989. Effect of xenobiotics on endomycorrhizal infection and isoflavonoid accumulation in soybean roots. Plant Physiol. Biochem. 27, 697-701.

Mujica, M.T., Fracchia, S., Ocampo, J.A., Godeas, A., 1999. Influence of the herbicides chlorsulfuron and glyphosate on mycorrhizal soybean intercropped with the weeds Brassica campestris or Sorghum halepensis. Symbiosis 27, 73-81.

O'Connor, P.J., Smith, S.E., Smith, F.A., 2002. Arbuscular mycorrhizas influence plant diversity and community structure in a semiarid herbland. New Phytol. 154, 209-218.

Olff, H., Ritchie, M.E., 1998. Effects of herbivores on grassland plant diversity. Trends Ecol. Evol. 13, 261-265.
Omacini, M., 2014. Asexual endophytes of grasses: invisible symbionts, visible imprints in the host neighbourhood. In: Verma, V.C., Gange, A.C. (Eds.), Advances in Endophytic Research. Springer, Verlag, pp. 143-157.

Padgette, S.R., Kolacz, K.H., Delannay, X., Re, D.B., LaVallee, B.J., Tinius, C.N., Rhodes, W.K., 1995. Development, identification, and characterization of a glyphosatetolerant soybean line. Crop Sci. 35, 1451-1461.

Pasaribu, A., Mohamad, R.B., Awang, Y., Othman, R., Puteh, A., 2011. Growth and development of symbiotic Arbuscular mycorrhizal fungi, Glomus mossea (Nicol. And Gerd), in alachlor and glyphosate treate soils. Afr. J. Biotechnol. 10, $11520-11526$.

Perelman, S.B., León, R.J.C., Oesterheld, M., 2001. Cross-scale vegetation patterns of Flooding Pampa grasslands. J. Ecol. 89, 562-577.

Powell, J.R., Campbell, R.G., Dunfield, K.E., Gulden, R.H., Hart, M.M., Levy-Booth, D.J. Klironomos, J.N., Pauls, K.P., Swanton, C.J., Trevors, J.T., Antunes, P.M., 2009. Effect of glyphosate on the tripartite symbiosis formed by Glomus intraradices, Bradyrhizobium japonicum, and genetically modified soybean. Appl. Soil Ecol. 41, $128-136$.

Reddy, K.N., Hoagland, R.E., Zablotowicz, R.M., 2001. Effect of glyphosate on growth, chlorophyll, and nodulation in glyphosate-resistant and susceptible soybean (Glycine max) varieties. J. New Seeds 2, 37-52.

Reddy, K.N., Zablotowicz, R.M., 2003. Glyphosate-resistant soybean response to various salts of glyphosate and glyphosate accumulation in soybean nodules. Weed Sci. 51, 496-502.

Rhoades, J.D., 1982. Soluble salts. In: Page, A.L., Miller, R.H., Keeney, D.R. (Eds.), Methods of Soil Analysis, Part 2 American Society of Agronomy. Madison, Wisconsin, pp. 161-179.

Rhoades, J.D., Chanduvi, F., Lesch, S.M., 1999. Soil Salinity Assessment: Methods and Interpretation of Electrical Conductivity Measurements. Food and Agriculture Organization of the United Nations.

Robinson, C.H., Wookey, P.A., Lee, J.A., Callaghan, T.V., Press, M.C., 1998. Plant community responses to simulated environmental change at a high artic polar semi-desert. Ecology 79, 856-866.

Rodriguez, A.M., Jacobo, E.J., 2010. Glyphosate effects on floristic composition and species diversity in the Flooding Pampa grassland (Argentina). Agric. Ecosyst. Environ. 138, 222-231.

Ronco, M.G., Ruscitti, M.F., Arango, M.C., Beltrano, J., 2008. Glyphosate and mycorrhization induce changes in plant growth and in root morphology and architecture in pepper plants (Capsicum annuum L.). J. Hortic. Sci. Biotechnol. 83 497-505.

Rusch, G.M., Oesterheld, M.N., 1997. Relationship between productivity, and species and functional group diversity in grazed and non-grazed Pampas grassland. Oikos 78, 519-526.

Savin, M., Purcell, L., Daigh, A., Manfredini, A., 2009. Response of mycorrhizal infection to glyphosate applications and P fertilization in glyphosate-tolerant soybean, maize, and cotton. J. Plant Nutr. 32, 1702-1717.

Schalamuk, S., Cabello, M., 2010. Arbuscular mycorrhizal fungal propagules from tillage and no-tillage systems: possible effects on Glomeromycota diversity. Mycologia 102, 261-268.

Scheublin, T.R., Van Logtestijn, R.S.P., Van Der Heijden, M.G.A., 2007. Presence and identity of arbuscular mycorrhizal fungi influence competitive interactions between plant species. J. Ecol. 95, 631-638.

Sheng, M., Hamel, C., Fernandez, M.R., 2012. Cropping practices modulate the impact of glyphosate on arbuscular mycorrhizal fungi and rhizosphere bacteria in agroecosystems of the semiarid prairie. Can. J. Microbiol. 58, 990-1001.

Singh, G., Wright, D., 2002. Effects of herbicides on nodulation and growth of two varieties of peas (Pisum sativum). Acta Agron. Hung. 50, 337-348.

Singleton, P.W., El Swaify, S.A., Bohlool, B.B., 1982. Effect of salinity on Rhizobium growth and survival. Appl. Environ. Microbiol. 44, 884-890.

Smith, S.E., Read, D.J., 2008. Mycorrhizal Symbiosis. Academic Press, London.

Smith, S.E., Smith, F.A., Jakobsen, I., 2003. Mycorrhizal fungi can dominate phosphate supply to plants irrespective of growth responses. Plant Physiol.133, 16-20.

Somasegaran, P., Hoben, H.J., 1985. Methods in Legume-Rhizobium Technology. NIFTAL project and MIRCEN, University of Hawaii, Paia.

Sprent, J.I., 2007. Evolving ideas of legume evolution and diversity: a taxonomic perspective on the occurrence of nodulation. New Phytol. 174, 11-25.

Sugavanam, V., Udaiyan, K., Manian, S., 1994. Effect of fungicides on vesiculararbuscular mycorrhizal infection and nodulation in groundnut (Arachis hypogea L.). Agric. Ecosyst. Environ. 48, 285-293.

Taboada, M.A., Rubio, G., Chaneton, E.J., 2011. Grazing impacts on soil physical, chemical, and ecological properties in forage production systems. In: Hatfield, J. L., Sauer, T.J. (Eds.), Soil Management: Building a Stable Base for Agriculture. Soil Science Society of America, pp. 301-320.

Tikhonovich, I.A., Provorov, N.A., 2007. Cooperation of plants and microorganisms: getting closer to the genetic construction of sustainable agro-systems. Biotechnol. J. 2, 833-848.

Tilman, D., 1994. Competition and biodiversity in spatially structured habitats. Ecol. $75,2-16$.

Tilman, D., Fargione, J., Wolff, B., D'Antonio, C., Dobson, A., Howarth, R., Schindler, D., Schlesinger, W.H., Simberloff, D., Swackhamer, D., 2001. Forecasting agriculturally driven global environmental change. Science 292, 281-284.

van der Heijden, M.G.A., Bakker, R., Verwaal, J., Scheublin, T.R., Rutten, M., Van Logtestijn, R., Staehelin, C., 2006. Symbiotic bacteria as a determinant of plant community structure and plant productivity in dune grassland. FEMS Microbiol. Ecol. 56, 178-187. 
van der Heijden, M.G.A., Bardgett, R.D., van Straalen, N.M., 2008. The unseen majority: soil microbes as drivers of plant diversity and productivity in terrestrial ecosystems. Ecol. Lett. 11, 296-310.

van der Heijden, M.G.A., Boller, T., Wiemken, A., Sanders, I.R., 1998a. Different arbuscular mycorrhizal fungal species are potential determinants of plant community structure. Ecology 79, 2082-2091.

van der Heijden, M.G.A., Klironomos, J.N., Ursic, M., Moutoglis, P., Streitwolf-Engel, R., Boller, T., Wiemken, A., Sanders, I.R., 1998b. Mycorrhizal fungal diversity determines plant biodiversity, ecosystem variability and productivity. Nature 396, 69-72.

van der Putten, W.H., Peters, B.A.M., 1997. How soil-borne pathogens may affect plant competition. Ecology 78, 1785-1795. van der Putten, W.H., van der Stoel, C.D., 1998. Plant parasitic nematodes and spatiotemporal variation in natural vegetation. Appl. Soil Ecol. 10, 253-262.

Walker, C., Mize, C.W., McNabb Jr., M., 1982. Populations of endogonaceous fungi at two locations in central Iowa. Can. J. Bot. 60, 2518-2529.

Zabaloy, Gómez, M.A., 2005. Diversity of rhizobia isolated from an agricultural soil in Argentina based on carbon utilization and effects of herbicides on growth. Biol. Fertil. Soils 42, 83-88.

Zablotowicz, R.M., Reddy, K.N., 2004. Impact of glyphosate on the bradyrhizobium japonicum symbiosis with glyphosate-resistant transgenic soybean. J. Environ. Qual. 33, 825-831.

Zahran, H.H., 1999. Rhizobium-legume symbiosis and nitrogen fixation under severe conditions and in an arid climate. Microbiol. Mol. Biol. Rev. 63, 968-989. 